\title{
Identification of the Parent Activity in helping the development of social skills - Emotional children ages 5-6 Years in Kindergarten Independent Islamic, Percut Sei Tuan, Medan Deli Serdang Regency. TA. 2018-2019
}

\author{
Nur Dwi Febrianti ${ }^{1}$, Anita Yus ${ }^{2}$, Yusnadi ${ }^{2}$ \\ ${ }^{1}$ Postgraduate Student, in Universitas Negeri Medan, Indonesia \\ ${ }^{2}$ Postgraduate Lecturer, in Universitas Negeri Medan, Indonesia \\ lailynurlina@ump.ac.id
}

\section{Abstract}

This event will be based on research to find out the parent activity in helping develop social-emotional ketermpilan ages of 5-6 years in the accompanying children, establish good communication with the child, give a chance in children, keep an eye on children in order to remain controlled, encouragement or motivation of the child, redirect the child to have and develop the basics of self discipline. This research aims to know the social-emotional skills development of children ages 5-6 years in Islamic kindergarten independent subdistrict of percut sei tuan deli serdang district ta. 2018 - 2019 and to know activities performed parents in cleaner development of social skills-emotional children aged 5-6 years in Islamic kindergarten independent sub-district of percut sei tuan deli serdang district ta. 2018-2019. The methods used are qualitative research methods. The data source that is taken is the father who served as head of the household and the mother who served as housewives in a kindergarten independent Islamic as much as 5 (five) head of the family that serves as the source of the informant. The results showed that there is a difference between the children who accompanied the same parents with children who are not accompanied by her parents in helping the development of the social-emotional skills of children aged 5-6 years in kindergarten independent Islamic with children who are not accompanied by her parents in helping the development of the social-emotional skills of children aged 5-6 years in kindergarten independent Islamic in associating with other people by way of doing activities together with teachers and classmates, follow instructions with how to accomplish the task as instructed, to identify and manage those emotions and behavior in a manner express themselves in accordance with the emotional conditions indicated, thinking of the right solution to conflict with how to determine the right way if you're having difficulty, hang on to the task by means of the task given to the penyele saian, and engage in social conversations and cooperative play by taking the initiative to invite friends to talk.
Keywords

the activity of the parent; socialemotional skills development of children ages 5-6 years

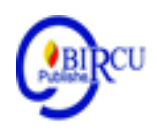

\section{Introduction}

As the process of growth and development, a child will go through stages of development with different development tasks, the success of achieving a developmental task at one stage will help smooth the next stage. This shows that the child is said to develop 
normally if the child can complete the tasks that must be lived at that time. Conversely, if the child is unable to complete the tasks that must be lived it can be said that the child experiences obstacles in its development. Every child grows and develops through the process of learning about himself and the world around him.

This learning process continues and continues throughout one's lifetime, starting from the age of infancy to reaching adulthood. When children begin to age, the world also develops from the home world and goes to the outside world. To be able to function well in a child's environment of life and learn to know himself and form a personal identity. Children also learn the process of social interaction and recognize the similarities and differences they have with others around them. Together with the learning process, children also experience growth and development in themselves, both physically and mentally. These developments include social-emotional development. The growth of social-emotional takes place continuously and varied in the process of child development.

Learning model is a plan or a pattern that is used as a guide in planning learning in class or learning in tutorials and to determine learning tools including books, films, computers, curriculum and others. (Suryono in Akrim, 2020) Meanwhile according to Soekamto, et al. (Giri Wiarto in Akrim, 2020) learning models have meaning, namely: Learning model is a conceptual framework that describes a systematic procedure in organizing learning experiences to achieve certain learning goals, and serves as a guide for learning designers and instructors in planning teaching and learning activities.

Children have the right and opportunity to develop according to their potential. According to Law No. 23 of 2002 concerning the Rights and Obligations of Children Article 10 states that: every child has the right to express and be heard, accept, seek and provide information in accordance with the level of intelligence and age for the development of himself in accordance with the values of decency and propriety. The development of socialemotional skills is the child's ability to respond to one's behavior in the form of feelings or vibrations of the soul that are marked by biological changes that occur accompanying the occurrence of a behavior that is in accordance with the norms.

\section{Research Methods}

According to Muri (2014: 327) the validity of the data used in this study is to use the triangulation technique of methods and sources. Triangulation is one of the techniques in collecting data to get more accurate findings and interpretations of data. Triangulation is a data validity checking technique that utilizes something else, used to cross check data. This understanding is applied when wanting to know the activities of parents in helping the socialemotional development of children aged 5-6 years at the Independent Islamic Kindergarten Percut Sei District, Deli Serdang District, Medan. In this study, researchers conducted triangulation by comparing observational data with interview data and comparing the circumstances and perspectives of the subjects studied with the views or opinions of organizers and educators. Thus the ultimate goal of triangulation is to be able to compare information about the same thing, obtained from several parties so that there is assurance of data trust and avoid subjectivity from researchers, as well as checking data outside the subject. This method is done to test the honesty, subjectivity and ability to record data by researchers in the field. In this case, the researcher makes a comparison and checks the degree of trust obtained from the informants with different time and tools. 


\section{Discussion}

This study discusses the social-emotional development of children aged 5-6 years and the activities of parents in helping the development of social-emotional skills of children aged 5-6 years. However, before being reviewed about the activity of developing social-emotional skills of children aged 5-6 years, it was first examined about the development of socialemotional skills of children aged 5-6 years at school every day. According to Soemiarti (2003: 30), the development of children's social-emotional skills is related to all aspects of child development. Everyone will have emotions of pleasure, anger, annoyance in dealing with their daily environment. Another thing that influences this development is the development of children's social insight. Generally they have entered an environment where peers have begun to influence their daily lives. The development of social-emotional skills of children aged 5-6 years in this study include:

\subsection{Hang out with others}

Associating with other people in question is doing activities with parents, teachers and friends who are in school. But in doing activities with the teacher and classmates in groups children must be brave and do activities with parents, teachers and friends at school in a fun way to avoid conflicts such as there are still children who choose the friends they want in the group, there are still children who do not want to hang out with a group of friends who have been chosen by their teacher and there are still children who feel afraid when doing activities with teachers and classmates in groups if not accompanied by his mother.

\subsection{Follow the instructions}

Following the instructions in question is completing the task as instructed. In following the instructions the child should be able to complete the task as instructed by his teacher. But in following the instructions the child should be able to complete the task as instructed by his teacher independently so that conflict does not occur as there are still children who are less eager to complete the task instructed by the teacher independently and there are still children who cannot complete the task that the teacher ordered independently without accompanied by his mother.

\subsection{Identifying and Managing Emotions and Behaviors with Others}

Identifying and regulating emotions and behavior with other people in question is expressing yourself in accordance with the emotional conditions indicated. But in identifying and managing people's emotions and behavior children should be able to express themselves in accordance with the emotional conditions shown by children. For this reason, teachers and parents know the emotions and behavior of each child to avoid conflicts such as there are children crying when their friends tease, there are still children who like to disturb their friends and there are still children who cry when left by their parents.

\subsection{Thinking About The Right Solution For Conflict}

Thinking about the right solution for the conflict in question is determining the right way if experiencing difficulties. But in thinking of the right solution for conflict children should be able to determine the right way if experiencing difficulties. For this reason, parents and teachers know the solution to every conflict that occurs in children to avoid conflicts such as there are still children who ask for help from their friends if experiencing difficulties and there are still children who ask for help from their mothers if experiencing difficulties.

\subsection{Stick to the task}

Sticking to the task in question is to do the work given for completion. But in sticking to the task the child should be able to do the task given for completion. For this reason, teachers should provide varied and fun learning for children to avoid conflicts such as there 
are still children who are less capable of doing the assignments given by their teacher and there are still children who are unable to work on assignments to complete independently without being accompanied by their mother due to motor skills less developed children.

\subsection{Engaged in conversation and social}

Play engaging in conversation and social play in question is taking the initiative to invite friends to talk. But in engaging in conversation and social play, children should be able to take the initiative to invite friends to talk. For this reason parents and teachers should participate in conversations and social play with children to avoid conflicts such as there are children who choose to talk to friends and playmates they want and there are still children who feel afraid to talk and play if not accompanied by his mother. According to Anita's article (2017) the adoption of Smith in Carrie Shrier (2014) the development of socialemotional skills of children aged 5-6 years who want to be formed namely: 1) associating with others by doing activities with parents, teachers and friends who are in school. 2) follow the instructions by completing the task as instructed. 3) identify and regulate emotions and behavior with others by expressing themselves according to the emotional conditions indicated. 4) think of the right solution if the conflict by determining the right way if experiencing difficulties. 5) stick to the task by working on the task given for completion. 6) engage in conversation and play socially by taking the initiative to invite friends to talk. The development of social-emotional skills of children aged 5-6 years is very important for subsequent child development. To be able to develop the socio-emotional skills of children aged 5-6 years, parents' activities are needed to help develop the socio-emotional skills of children aged 5-6 years, children develop well

\section{Conclusion}

1. Development of social-emotional skills of children aged 5-6 years at Islamic Kindergarten Mandiri, namely: being able to get along with others by doing activities with the teacher and classmates, can follow the instructions by completing tasks as instructed, can identify and regulate emotions and behavior with others by expressing themselves in accordance with the emotional conditions indicated, can think of the right solution if the conflict by determining the right way if experiencing difficulties, can survive on the task by doing the tasks assigned to completion, can engage in conversation and play socially by taking the initiative to invite friends to talk.

2. Activities undertaken by parents in helping the development of social-emotional skills of children aged 5-6 years at Islamic Kindergarten Mandiri, namely: accompanying children by giving attention to children in accompanying children to play, establish communication by talking with children, provide opportunities for children by giving trust to children without the need for supervision, supervising children by paying attention to children to stay controlled, encouraging or motivating children by giving children praise or gifts, directing children to have the basics of self-discipline by directing children to behave the do's and don'ts through the experience or stimulation they receive.

\section{References}

Akkrim . (2020). Application of Learning Model Strategies to improve Islamic Learning Outcomes. Budapest International Research and Critics Institute-Journal (BIRCIJournal). P. 1157-1166.

Amini Mukti. (2015). Profil Keterlibatan Orang Tua Dalam Pendidikan Anak Usia Tk. Jurnal Ilmiah VISI PPTK PAUDNI - Vol. 10, No.1. 
Candra, Puspita Oky. (2013). Upaya Pendidik Dalam Proses Pengembangan Sosial Emosi Anak Usia Dini Di Kelompok Bermain Mardi Utomo I Kecamatan Sarang Kabupaten Rembang. Journal of Non Formal Education and Community Empowerment. ISSN 2252-6331

E.R, Djazifah. (2007). Keluarga Sebagai Titik Awal Perkembangan Sosial Anak Usia Dini. Jurnal Pendidikan Luar Sekolah, Edisi 6, Nomor 2. ISSN: 0854-396X

Undang - Undang Peraturan Menteri No 137 Tahun (2014). Standar Tingkat Pencapaian Perkembangan Anak

Undang - Undang Sistem Pendidikan Nasional No. 20 Tahun (2003). Hak Dan Kewajiban Orangtua.

Undang - Undang Sistem Pendidikan Nasional No. 23 Tahun (2002). Hak Dan Kewajiban Anak.

Yus Anita. et al. (2017). Models of Portfolio-Based Teaching as a Early Childhood Social Emotional Skills Development Strategy. Kemajuan dalam ilmu sosial, pendidikan dan penelitian humaniora, volume 2104 tahunan Seminar Internasional transformatif pendidikan dan pendidikan kepemimpinan (AISTEEL 2017) Copyright (C) 2017, penulis. Diterbitkan oleh Atlantis Press. Ini adalah artikel akses terbuka di bawah lisensi CC BY-NC (http://creativecommons.org/licenses/by-nc/4.0/). 